\title{
Microbiological Assessment Of Date Fruits Purchased From Owode Market, In Offa, Kwara State Nigeria.
}

\author{
Raimi Olayinka Risiquat \\ Department of Applied Sciences, Osun State Polytechnic P.M.B 301 Iree Osun State, Nigeria.
}

\begin{abstract}
Hard and soft dates sold in nylon were purchased from owode market in Offa, Kwara state, Nigeria. The bacteria load ranged from $4 \times 10^{5}-19 \times 10^{5}$ and $10 \times 10^{5}-20 \times 10^{5}$ respectively. The bacteria isolated were Staphylococcus aureus, Streptococcus species, Proteus mirabilis, Enterobacter species, Escherichia coli and Salmonella species. The coliform count were between 3-9 in hard date fruits and 11-23 in soft date fruit respectively. Mould count were $1.0 \times 10^{2}-2.8 \times 10^{2}$ and $4.8 \times 10^{3}-7.2 \times 10^{3}$ while yeast count were $1.6 \times 10^{2}-$ $8.2 \times 10^{3}$ and $5 \times 10^{4}-16 \times 10^{4}$ respectively. All these values were above the Saudi specification. Therefore these samples cannot be recommended for human consumption. A means of preserving dates fruit from microbial contamination and spoilage should be discovered, also storing in hygienic conditions is important before selling to the populace for consumption to prevent the spread of infection and diseases.
\end{abstract}

Keywords: Date palm(phoenix dactilyfera L.), Staphylococcus aureus, Escherichia coli, Salmonella species, mould yeast, contamination, pathogenic

\section{Introduction}

The date palm (Phoenix dactylifera $\mathrm{L}$.) is one of mankind's oldest cultivated plants. It has been used as food for 6000 years (W. M. Amer 1994). It could be used for generations to come due to its remarkable nutritional, health and economic value, in addition to its aesthetic and environmental benefits. Every part of the date palm is useful. Dates offer useful prospects for fighting hunger and diseases. Dates (Phoenix dactylifera $\mathrm{L}$.) are mainly grown in Middle East and North African countries, with a worldwide annual production of about 6 million tones. Saudi Arabia produces yearly about 900 thousand tones and ranks as the third largest producer in the world (FAO, 2008). About 50\% of the produce in Saudi Arabia is consumed locally as human food, only about $4 \%$ is exported, while the rest is mainly used as animal feed ( $\mathrm{Al} \mathrm{Eid,} \mathrm{2010).}$

A date palm fruit is an important component of the diet in most of the hot arid and semi arid regions of the world. It is found to contain carbohydrates (total sugars $44 \%-88 \%)$, fats $(0.2 \%-0.4 \%)$, proteins $(2.3 \%-5.6$ $\%)$, fibers $(6.4 \%-11.5 \%)$, minerals and vitamins (W. M. Amer 1994).

Carbohydrates in dates are mostly in the form of fruc-tose and glucose, which are easily absorbed by the human body. Interestingly, dates contain high concentrations of protein when compared to other cultivars of fruits such as apples, oranges, bananas and grapes $(0.3 \%, 0.7 \%, 1.00 \%$, and $1.00 \%$ proteins, respectively).Showiman (S. S. Al-Showiman 1998).

Twenty three different amino acids were found in date's proteins, many of which are not found in the most popular fruits (M. Al-Farsi et al 2005). There are more than 2000 different varieties of fresh dates [1]. Many fresh varieties are available throughout 8 months of the year. Packed, dry dates keep well without the addition of preservatives for at least 8 months, the high sugar content acting as an effective preservative.

Microbial contamination, especially with molds, is a major obstacle facing international marketing of Saudi dates (Al Eid, 2010). Dates are fairly dry fruits, with water and sugar contents of $10-15 \%$ and $60-88 \%$ (on dry basis), respectively (Barreveld, 1993), hence they are generally regarded as stable to microbial spoilage. However some contaminants, especially osmotolerant yeasts and molds, may survive for longer times or even grow on the fruits. Microbial contaminants isolated from date fruits include yeasts, molds, lactic acid bacteria and some potential pathogens like Staphylococcus aureus E. coli, and A. flavus/parasiticus (Bolin et al., 1972; Abu-Zinada and Ali, 1982; El-Sherbeeny et al., 1985; Nussinovitch et al., 1989; Abdulsalam et al.,1991; Aido et al., 1996; Kader 2007; Hamad, 2008).

\section{Collection of Samples}

\section{Materials And Method}

Dates fruits (Phoenix dactylifera L.) were purchased from owode market in Offa, Kwara state of Nigeria. Hard and soft date palm fruit Samples were picked randomly from the seller, to assure a good representation. The samples were cleaned by removal of foreign matter and taken in Polyethylene bags with labels and brought the laboratory for analysis immediately. 


\section{Preparation of Date Fruits for Analysis}

The sample collected were cleaned and pitted; $10 \mathrm{~g}$ of hard and soft date were aseptically weighed into sterile stomacher bags and $90 \mathrm{ml}$ distilled water added. Samples were then homogenized for 10minutes and aliquot were used for microbiological analysis.

\section{Microbiological Analysis}

To determine total viable count, $1 \mathrm{ml}$ of aliquot of hard and soft dates were serially diluted in $9 \mathrm{ml}$ of distilled water respectively. $1 \mathrm{ml}$ aliquots from suitable dilution $\left(10^{3}-10^{5}\right)$ were transferred aseptically into sterile Petri-dishes. To each dilution $10-15 \mathrm{ml}$ of melted and cooled to $\left(45^{\circ} \mathrm{C}\right)$, Nutrient were added; Inoculum was mixed well with the medium and allowed to solidify. The plates were then incubated at $37^{\circ} \mathrm{C}$ for $24-48$ hours.

Inoculum were streaked on nutrient agar, mannitol salt agar, Mac-Coney agar and Deoxy Cholate citrate agar (DCA). Incubated at $37^{\circ} \mathrm{C}$ for $24-48$ hours. Pure culture were made by sub-culturing on nutrient agar plate, using the streaked plate method until a pure culture was obtained.(Monica cheesebrough, 1984). Morphological characteristics, Gram staining and biochemical test were used to confirm the bacteria isolated. (Monica cheesbriugh 1984).

The coliform test was performed by placing $9 \mathrm{ml}$ double strength Lactose broth in 3 test tubes and $9 \mathrm{ml}$ single strength in six-test-tubes, three tube containing double strength were inoculated with $10 \mathrm{ml}$ of the aliquot, three tubes containing single strength Lactose broth were inoculated with $1 \mathrm{ml}$ of aliquot, while the last 3 testtubes were inoculated with $0.1 \mathrm{ml}$ of original stock culture, Durham tubes were inverted into these tubes and gas bubbles were removed to prevent false positive result. The mouth of the test-tubes were plugged with cotton wool, wrapped with foil and were incubated at $37^{\circ} \mathrm{C}$ for 48 hours; then change in colour and gas production were observed. The confirmed tests were done by inoculating Mac-Conkey agar plate with $1 \mathrm{ml}$ positive presumptive test- in tubes by streaking respectively. The plates were incubated at $37^{\circ} \mathrm{C}$ for 24 hours. Colonies from these were sub-cultured on Eosin methylene blue agar (the completed test), incubated at $37^{0} \mathrm{C}$ for $24-48$ hours.

Isolation of mould and yeast cell were done by stabbing Potatoe dextrose agar plate and Malt extract plate with an inoculum from aliquot grounded with grinder. Another set of plates were inoculated with $0.5 \mathrm{ml}$ inoculum from $\left(10^{4}-10^{5}\right)$ and spread by glass spreader, incubated at $27^{0} \pm 1$ for 3-5 days. Growth were observed and recorded.

\section{Results And Discussion}

The total bacterial viable count for Hard date fruit were between $8 \times 10^{5}-19 \times 10^{5} \mathrm{Cfu} / \mathrm{ml}$. The soft date fruits were $10 \times 10^{5}-20 \times 10^{5} \mathrm{Cfu} / \mathrm{ml}$. This is shown in Table 1 below.

Table 1 Showing bacterial and Coliform count from Dates fruit Phoenix Dactylifera

\begin{tabular}{|c|c|c|c|l|}
\hline \multicolumn{3}{|c|}{ BACTERIAL VIABLE COUNT } & \multicolumn{2}{c|}{ COLIFORM COUNT } \\
\hline S/N & HARD & SOFT & HARD & SOFT \\
\hline 1 & $19 \times 10^{5}$ & $20 \times 10^{5}$ & 3 & 11 \\
\hline 2 & $8 \times 10^{5}$ & $14 \times 10^{5}$ & 7 & 18 \\
\hline 3 & $4 \times 10^{5}$ & $10 \times 10^{5}$ & 9 & 23 \\
\hline
\end{tabular}

Table 2 Showing mould count and Yeast Viable count from dates fruits Phoenix Dactylifera

\begin{tabular}{|c|c|c|c|c|}
\hline \multicolumn{3}{|c|}{ MOULD COUNT } & \multicolumn{2}{c|}{ YEAST VIABLE COUNT } \\
\hline S/N & HARD & SOFT & HARD & SOFT \\
\hline 1 & $1.0 \times 10^{2}$ & $4.8 \times 10^{3}$ & $3.0 \times 10^{3}$ & $5 \times 10^{4}$ \\
\hline 2 & $1.4 \times 10^{2}$ & $6.0 \times 10^{3}$ & $1.6 \times 10^{2}$ & $10 \times 10^{4}$ \\
\hline 3 & $2.8 \times 10^{2}$ & $7.2 \times 10^{3}$ & $8.2 \times 10^{3}$ & $16 \times 10^{4}$ \\
\hline
\end{tabular}

The bacteria counts were very high in both the hard and soft Date fruit Phoenix Dactylifera in table 1. The values obtained were much higher than the recommended value for food $<10^{4} \mathrm{Cfu} / \mathrm{ml}$.(Ossai ochonogor Samuel, 2012) This implies extreme contamination and potential health risk; these findings correlated with similar earlier study (Olukoya et al 1991; Mensah et al 2002; Yahoah Manu et al 2010). The high incidence of bacterial contamination are mainly due to unsanitary and largely unhygienic nature of selling conditions and environment which are good indicator of the state of environment in which the dates are being sold. Majority of these fruits are close to waste disposal point or dusty road or street with human and vehicular traffic which 
encourage multiple contamination due to the deposition of bioaerosol on the exposed fruits also transfer from one hands and flies also lead to contamination (Yassin and Almouqatea 2010).This show the date fruits were highly contaminated, and therefore make the date fruit unfit for consumption. The total bacteria viable count usually indicates the general microbiological quality of date fruits (Moore et al 2001). The bacteria isolated were Staphylococcus aurues, Staphylococcus species, Streptococcus species, Proteus mirabilis, Enterobacter species, Escherichia coli and Salmonella species. All the bacteria isolated are pathogenic and can lead to serious diseases especially in the case of Salonella, Staphylococcs and Escherichia coli which are known pathogens that can cause serious infections damages to organs and can lead eventually to death. The coliform count were between 3-9 in hard date fruit and 11-23 in soft date fruit, though this values were below 100, recommended values for coliform count in foods(Ossai ochonogor Samuel, 2012), but it still confirm faecal contamination from the environment ,like from the aerosol in the environment or handling and the selling condition in the market. Coliform bacteria chiefly faecal coliform are enteric bacteria, whose natural habitat is the intestinal tracts of humans and animals (Pelczar et al 2005). They are faecal indicators, and their isolation in hard and soft dates fruits indicates the presence of faecal contamination from the unsanitary environment or via human handler (Pelczar et al 2005). The isolation of coliform bacteria in all the dates fruits samples makes these fruits hazardous for human consumption. The isolated enteric bacteria are known pathogens responsible for millions of cases of infectious gastro intestinal diseases and death in each year.

Yeast cells counts in hard dates fruits were between $1.6 \times 10^{2}$ to $8.2 \times 10^{3}$. on the other hand, date fruit with soft cotyledons have yeast count which ranged from $5 \times 10^{4}$ to $16 \times 10^{4}$ values obtained in this case were high and above recommended value, thereby making it unfit for human consumption. The limit for yeast contamination in date fruits according to the Saudi standard specification are in 2 out of 5 replicate tested from a sample the targeted limit is $10 \mathrm{Cfu} / \mathrm{g}$ and no implicate should reach a load of $10^{2} \mathrm{Cfu} / \mathrm{g}$ (SASO, 1999). The mould counts were $1 \times 10^{2}-2.8 \times 10^{2}$ in hard date and $4.8 \times 10^{3}-7.0 \times 10^{3}$ in soft dates (Table 2). This also is a high level of contamination, the limits for mould contamination in date fruits according to Saudi Standard Specifications are (these specifications include limits for moulds, Yeast and $E$ coli only): in 2 out of 5 replicate tested from a sample the targeted limit is $10^{2} \mathrm{Cfu} / \mathrm{g}$ and no replicate should reach a load of $10^{3} \mathrm{Cfu} / \mathrm{g}$ (SASO, 1999). In hard date examined two out of the three samples $(2,3)$ examined (Table 2) were therefore out of specification, also all the soft date were with load of $10^{3} \mathrm{Cfu} / \mathrm{g}$ because they contained more than $10^{2} \mathrm{Cfu} / \mathrm{g}$, hence only 1 sample therefore in hard date met the requirement for limits of Saudi specification. The high level of mould contamination may be due to the period of harvesting, if it is dry-windy month contamination can occur; airborne mould spores can easily contaminate the fruits of the tall palm trees. Contamination can also occur from the market environment and through handling. Studies by (Siddig Hussein hamad 2012) show that most microbial contamination of date die with time if the fruits are packaged and stored at refrigeration temperature. Date fruits are also known to contain some antimicrobial components. For example, some varieties contain up to 2.5\% tannis (Al-Hooti et al 1997; Myhara et al 2000) which have been reported to cause growth inhibition to many species of fungi and bacteria (Nelson et al 1997; Ishida et al 2006). Only some osmotolerant yeasts seem to be able to survive or grow in packaged date fruits stored under refrigeration conditions. The yeast cells and these mould isolated in most cases, causes food poisoning. Therefore, the date fruits are not good and dangerous for human consumption.

\section{Conclusion}

The result from present study shows that both the hard and soft dates purchased in nylon and open in wheel barrow from owode market in Offa, Kwara state were highly contaminated with pathogenic bacteria, mould and yeast. This makes it hazardous for human consumption. Therefore a way of storing and preserving date fruit should be considered before selling to the public for human consumption. A good method is by packaging and storing at low temperature in refrigerator.

\section{References}

[1]. Abdulsalam Khaled S., Ahmed A. Musa and Ahmed Abdulmohsin. 1991. The effect of three fungi and their combinations on the chemical constituents of two cultivars of date palm fruits. Emir. J. Agric. Sci. 3:81-95.

[2]. Abu-Zinada, A. H., and M. I. Ali. 1982. Fungi associated with dates in Saudi Arabia. J. Food Prot.45:842-844.

[3]. Aidoo, K. E., R. F. Tester, J. E. Morrison and D. MacFarlane. 1996. The composition and microbial quality of pre-packed dates purchased in Greater Glasgow. Int. J. Food Sci. Technol. 31:433- 438.

[4]. Al Eid, S. M. 2010. Date Palm Research Center, King Faisal University, Saudi Arabia. Personal communication, unpublished data.

[5]. Barreveld, W. H. 1993. Date palm production. FAO Agricultural Services bulletin 101. Food and Agriculture Organization, Rome.

[6]. Bolin, H. R., A. D. King, W. L. Stanely and L. Jurd. 1972. Antimicrobial protection of moisturized Deglet Noor dates. Appl. Microbiol. 4:799-802.

[7]. El-Sherbeeny, M. R., M. F. Saddik and F. L. Bryan. 1985. Microbial profiles of foods served by street vendors in Egypt. Int. J. Food Microbiol. 2:355-364.

[8]. FAO (UN Food and Agriculture Organization) 2008. "Date Palm." http://faostate.fao.org/ site/340/default.

[9]. Hamad, S. H. 2008. Microbial spoilage of date Rutab collected from the markets of Al-Hofuf City in the Kingdom of Saudi Arabia. Journal of Food Protection. 71(7):1406-1411. 
[10]. Ishida, K., J. C. P. de Mello, D. A. G. Cortez, B. P.D. Filho, T. Ueda-Nakamura and C. V. Nakamura. 2006. Influence of tannins from Stryphnodendron adstringens on growth and virulence factors of Candida albicans. J. Antimicrob. Chemother. 58:942-949.

[11]. Kader, A. A. 2007. Recommendations for maintaining postharvest quality. Department of Plant Science, University of California

[12]. Mensah, P, Yeboah, M.D, Owusu, D.K and Ablordey A. (2002). Street foods in Accra, Ghana: how safe are they? Bulletin of the World Health Organization, 80(7)546-554.

[13]. M. Al-Farsi, C. Alaslvar, A. Morris, M. Baron and F. Shahidi, "Comparison of Antioxidant Activity,Antho-cyanins, arotenoids and Phenolics of Three Native Fresh and Sun Dried Date (Phoenix dactylifera L.) Varieties Grown in Oman," Journal of Agricultural and Food Chemistry, Vol. 53, 2005, 7592-7599.

[14]. Nelson, K. E., A. N. Pell, P. H. Doane, B. I. Giner-Chavez, and P. Schofield. 1997. Chemical and biological assays to evaluate bacterial inhibition by tannins. J. Chem. Ecol. 23:1175- 1194.

[15]. Nussinovitch, A., B. Rosen, H. Salik, and I. J. Kopelman. 1989. Effect of heating media on the microbiology and shelf life of heat pasteurized soft dates. Lebensm. Wiss. Technol. 22:245- 247.

[16]. Olukoya, D.K, Bakare, S.B and Abayomi O. (1991). Micorbiological evaluation of Food samples sold to Primary School Children in Lagos, Nigeria. Journal of tropical Paediatrics, 37:245-252.

[17]. Ossai ochonogor Samuel 2012, bacteriological quality and safety of street vended foods in Delta state Nigeria. Journal of Biology, Agriculture and Healthcare ISSN 2224-3208.

[18]. Pelczar, M.J, Chan, E.C.S, and Noel, R.K.C, (2005). Microbiology (15 ${ }^{\text {th }}$ ed.) Tata Mc Graw Hill. New Delhi, 571.

[19]. Saudi Standards, Metrology and Quality Organization (SASO). 1999. Microbiological limits for Food materials No. 1556, Kingdom of Saudi Arabia.

[20]. Siddig Hussein hamad 2012, the microbial quality of processed date fruits collected from a factory in Al-Hofuf City, Kingdom of Saudi Arabia. Emir. J. Food Agric. 2012. 24 (2): 105-112.

[21]. S. S. Al-Showiman, "Al Tamr, Ghetha wa Saha (Date, Food and Health)," Dar Al-Khareji Press, Saudi Arabia, 1998.

[22]. W. M. Amer, "Taxonomic and Documentary Study of Food Plants in Ancient Egypt,” Ph.D. Thesis, Cairo Uni-versity, Giza, 1994.

[23]. W. M. Amer, "Taxonomic and Documentary Study of Food Plants in Ancient Egypt," Ph.D. Thesis, Cairo Uni-versity, Giza, 1994.

[24]. Yahoah, Manu, D.G, Kpeli, M, Akyeh, M and Bini, L (2010). Bacteriological Quality of Ready to eat foods sold on and around University of Ghana Campus. Res. Jour. Microbiol. 5:130-136. 